servations during the eclipse would communicate with the honorary secretary, Dr. W. Eccles, University College, London, W.C., at the earliest possible date. The committee proposes to prepare and circulate special forms for the collection of statistics of signals and strays, especially within the hemisphere likely to be affected by the eclipse. It will endeavour to make provision for the transmission of special signals at times to be indicated on the forms. It will also offer for the consideration of the authorities controlling stations near the central line a simple programme of work. The discussion of the observations, and the comparison with meteorological data will be carried out by the committee, and digests of the statistics, together with the conclusions drawn from the analysis, will be published in due course.

The Curious Meteoric Display of February 9, I 13.-A brief account was given in Nature of September is last (vol. xcii., p. 87) of what was described as an "extraordinary meteoric display," which was observed over a verv extensive line in Canada and America. The display took the form of a procession of meteors, brilliant and coloured, and was compared with a fleet of battleships or airships proceeding at night across the sky. The Journal of the Royal Astronomical Society of Canada for November-December, IgI3 (vol. vii., No. 6, pp. 404 and 438 ) publishes some further information and correspondence relating to this extraordinary display which will be read with great interest. In the first instance, Mr. W. F. Denning communicates an interesting discussion, having gone over the work again, after Prof. Chant's investigation, with the result of obtaining a good general agreement with the latter's conclusions. Even so experienced an observer as $\mathrm{Mr}$. Denning describes the fall as "unique." The further information is supplied by Col. W. R. Winter, of Bermuda, who has been able to collect additional facts since his first report. It shows that the general appearance of the display at Bermuda differed considerably from that observed in Canada, for most of the large leading bodies had disappeared while the number of trailers and groups had greatly increased. Prof. Chant discusses these various opinions and new observations in the article in question.

The Genieral Displacement of Lines in the Sol.ar Specrrum.-Some results of a comparison of arc and solar wave-lengths of certain iron lines appear in Bulletin No. xxxvi. of the Kodaikanal Observatory by which Mr. Evershed has been led to a new interpretation of the general displacement of lines in the solar spectrum towards the red. The completion of the electric installation has enabled use of the arc to obtain spectra of the sun and laboratory source of light on the same plate, thus permitting more accurate determination of absolute and relative shifts of the lines in the solar spectrum. Some of the plates have been measured by the positive on negative method recently noted in this column. Mr. Evershed's determination of the difference between sun and arc agree, in the main, very well with the figures which MM. Fabry and Buisson have obtained by the interference method. The pressure explanation of the origin of the shifts is now found to be quite incompatible with the observations in three different directions: (r) King's low-level lines show least shifts in the sun; (2) the lines showing greatest shifts under pressure in the laboratory show least shift in the sun; and (3) the lines in the red do not show the greatly increased shifts they would be expected to if Duffield's exponential law were followed. It is found that lines in the red show the least shifts, and that the strong (high-level lines) are most affected. These two facts NO. 23 I6, VOL. 93$]$ receive adequate explanation on the supposition that in the higher levels there is a movement of descent with a negative acceleration. The motion for the strong lines amounts to $0.93 \mathrm{~km}$. $/ \mathrm{sec}$, while for the weak lines it is less than $0.3 \mathrm{~km} . / \mathrm{sec}$. The director is to be congratulated on the early advantage he has taken of the increased facilities afforded by the completed electric installation.

Origin of Planetary Surface Features.- M. Emile Belot has communicated to the French Academy of Sciences a tentative theory of the mode of formation of the external features of some planetary bodies, more especially those of the earth (Comptes rendus, vol. clviii., p. 647). Whilst one does not feel by any means compelled to accept all the suggestions there put forward, the paper is nevertheless intensely interesting, and contains some highly original ideas regarding the development of the heart-shaped figure of the earth and the formation of land areas based on the hypothesis of a relative movement of translation of the earth (also the moon and Mars, which are regarded as resembling the earth) in the primitive nebula, the movement being in the direction of the axis of rotation from south to north. M. Belot regards the main land features as cognate with water. He supposes, indeed, that they were formed by the deposition of material carried by surface torroidal currents flowing away from the south pole, completing a stupendous circulation generated by the resistance offered by the nebula to the movement of translation. The vertical cool descending current in the Antarctic region marked that as the site of the condensation of the water of the ocean.

\section{SMOKE ABATEMENT IN EUROPE AND AMERICA.}

THE movement for lessening the evils of smoke, both factory and domestic, is extending and increasing in weight and importance. In our own country, the health authorities of sixteen cities have commenced to make accurate observations upon the extent and character of the soot- and dust-fall, by a standard method and apparatus.

Classes for the instruction of stokers and engineers in the scientific principles of combustion are now included in the curriculum of the majority of the larger technical schools and institutes; and a movement is in progress to obtain higher wages and a better status for the men who have passed satisfactorily through these courses of training, and have obtained a certificate of efficiency. Glasgow has made most progress in this direction, and has also carried on for several winters a series of popular lectures, designed to bring home to the general public the losses and evils arising from smoke, and the best methods of minimising these, both in the works and in the home. The classes and lectures have been carried on in Glasgow, by the West of Scotland Branch of the Smoke Abatement League; in Manchester, Liverpool, and other towns and cities, the classes are run by the local education authorities.

In Germany, the Hamburg "Verein für Feuerungsbetrieb und Rauchbekämpfung " continues to flourish, and can show a membership of nearly 500 members, the majority of whom own boilers or other heating appliances, and are thus large users of fuel. The officers of the Verein are now directing their attention to the emission of smoke from steamers lying in the port of Hamburg, and are seeking to extend the benefits of their system of supervision to the Mercantile Marine.

In America, the most notable event of the past twelve months has been the publication by the Mellon 
Institute of Industrial Rescarch in the University of Pittsburg of a series of bulletins dealing with the results of the inquiry into the black smoke problem in that district of the U.S.A. Five bulletins have been issued so far: No. I deals with the "Outline of the Investigation," No. 2 is a "Bibliography," No. 3 discusses the "Psychological Aspects of the Problem," No. 4 deals with the "Economic Cost of the SmokeNuisance in Pittsburg," and No. 5 with the "Meteorological Aspect of the Smoke Problem."

Bulletin No. 4 contains the following summary of the losses annually incurred in Pittsburg, as a result of the damage and dirt produced by smoke :-

(I) Cost to the smoke-maker, by imper-

fect combustion $\ldots$ Cost to the individual: laundry and dry-cleaning bills ... ... ... ...

(3) Cost to the householder: painting, cleaning, and decorating $\ldots \ldots$

(4) Cost to the proprieturs of wholesale and retail stores: cleaning, lighting,

depreciation of stock ...
(5) Cost to the owners of office buildings,

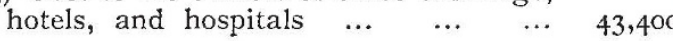

$$
\text { Total } \ldots \quad \ldots \quad f \longdiv { \mathrm { r } , 9 9 8 , 9 5 ^ { \circ } }
$$

This estimate, it must be noted, covers the losses per annum in one American city alone, the population of which at the present time is about $35^{\circ}, 000$. Calculated for each head of the population, the loss is therefore about $5 l$. $13 s$. per annum.

Assuming that London is only suffering pecuniary losses from the smoke evil to one-half the extent of Pittsburg, the total will represent a loss of well over ten million pounds per annum, or more than double the estimate given by the Hon. Rollo Russell, in a paper read at the Building Trades Exhibition and Conference, held in London in 1899.

\section{J. B. C. K.}

\section{THE AFRICAN MAMMAL FAUNA.}

F ROM a zoological point of view the year which has just come to a close will be noteworthy on account of the extraordinary number of new specific and subspecific names applied to members of the African mammal fauna. In the case of the larger forms a great proportion of these names have been proposed as the result of the detailed examination of the vast series of East African mammals collected during the Roosevelt expedition, by Mr. E. Heller, who, in various issues of the Smithsonian Miscellaneous Collections, has described as new a number of local races of monkeys, antelopes, and Carnivora. To some of these reference has been already made in NATuRE, with mention of the very slight differences by which many of the new races are distinguished. The same naturalist has also, during $19 \mathbf{I}_{2}$ and $\mathrm{I} 9 \mathrm{I} 3$, made several well-known antelopes the types of new genera, separating, for instance, the lesser kudu as Ammelaphus, and Hunter's hartebeest as Beatragus, the latter term being formed by combining "B.E.A.," the initials of British East Africa, with the Greek roíyos-a combination which would have made the classically educated naturalists of a previous generation recoil with horror.

Local races of the arui or North African wild sheep have been described in "Novitates Zoologicæ," by the Hon. Walter Rothschild, who has also, in the December issue of the Ann. Mag. Nat. Hist., given names to various local races of antelopes, among these being the Congo representative of the giant eland, which appears to be the largest form of that No. 23 I6, VOL. 93] species. A new race of the ordinary eland, as well as various monkeys, have been named by Dr. P. Matschie, respectively in the Sitzber. Ges. nat. Freunde and the Revue Zool. Africaine; while several local forms of antelopes have received new names from Mr. E. Schwarz in the Ann. Mag. Nat. Hist. Nor does this exhaust the list of antelopes, as $\mathrm{Mr}$. Gilbert Blaine, in the journal last cited, has named a new gazelle from Erythrœa, as well as two races of reedbucks.

Among the smaller mammals particular interest attaches to the description of a second species of the remarkable insectivorous genus Massoutiera from the Algerian Sahara, by Mr. O. Thomas, in vol. xx. of the "Novitates"; while various new African bats and shrews have been named by the same writer in two issues of the Ann. Mag. Nat. Hist. By far the largest number of additions to the list of African Micromammalia has, however, been made by $\mathrm{Mr}$. Austen Roberts, who, in vol. iv., part 2, of the Annals of the Transvaal Museum, has described as new no fewer than twenty-eight species and subspecies from the Transvaal and neighbouring South African States.

Although many of the races to which separate names have been applied during the year are undoubtedly worthy of recognition and distinction, those based on minute and unimportant colour-differences make the thoughtful naturalist wonder where the splitting process is to end, and what advantage accrues to science when it is carried to the excess which is now in vogue.

R. L.

\section{THE INSTITUTE OF METALS.}

$\mathrm{W}^{\mathrm{E}}$ have received a copy of the tenth volume of the Journal of the Institute of Metals, containing, principally, an account of the papers read and discussions at the autumn meeting of the institute, held at Ghent in September last. The volume reflects the flourishing state of the institute, which has now held its first meeting abroad, and with marked success.

The most important feature of the volume is the second report to the corrosion committee, in which Dr. Bengough and Mr. Jones, of Liverpool University, give an account of their work on this subject. This has included laboratory experiments and also trials with an experimental condenser erected with the funds collected by the corrosion committee. This somewhat costly form of investigation has, however, fully justified itself, and its continuance is assured by the further financial support received from some of those most interested in condenser-tube corrosion. The report constitutes an important forward step in our knowledge of the corrosion of brass by the process of "de-zincification." It is shown that in a simple $70 / 30$ brass this occurs normally in contact with sea-water, particularly if the temperature is raised to the vicinity of $40^{\circ} \mathrm{C}$. A white zinc-salt, of the nature of a basic chloride, is formed, and acts as a species of catalytic agent, leading to the continued solution of zinc with constant re-formation of the basic chloride. Muntz metal is found much inferior to brass in this connection, but a brass containing $I$ per cent. of tin, or, better still, 2 per cent. of lead, is found to resist this form of corrosion far better than a pure zinc-copper alloy. A remarkable result brought out by the report is the negligible influence exerted on dezincification by local electric cells, such as those formed by adherent particles of other metals or of carbon.

Among the other papers may be mentioned a further contribution to the theory of an amorphous intercrystalline cement, by Dr. Rosenhain and Mr. D. 